\title{
Özel Okullarda Öğrenci Başına Devlet Desteği Konusunda Öğretmen Görüssleri
}

\section{Teachers' Opinions on Government Support per Pupil in Private Schools}

\author{
Hüseyin ERGEN ${ }^{1}$ Tolga ALTINER ${ }^{2}$
}

\section{Anahtar Kelimeler \\ Öğretmen görüşleri özel okullar, \\ ortaokullar, ögrenci başına devlet desteği.}

\begin{abstract}
Özet
Bu çalışmanın amacı, kamu ve özel ögretim okullarında görev yapan öğretmenlerin özel okulda ögrenim gören ögrenci başına yapılan devlet desteğiyle ilgili görüşlerini ortaya koymaktır. Çalışmaya katılan ögretmenlerin özel okul öğrencilerine devlet desteği konusunda görüşleri farklı değişkenler açısından ele alınmıştır. Araşstırmaya Mersin ili Mezitli ilçesindeki ortaokullarda görev yapan gönüllü 119 ögretmen katılmıştır. Öğretmen görüşleri araştırmacılar tarafından geliştirilen, kişisel bilgi formu ve anketten oluşan bir veri toplama aracı aracılığı ile elde edilmiştir. Öğretmen görüşlerini belirlemeye yönelik anket ölçek tipinde 26 maddeden oluşmaktadır. Toplanan veriler üzerinde yapılan analizde frekans, yüzde ve fark analizleri kullanılmıştır. Elde dilen bulgulara göre medeni durum, lisans eğitimi ve branş değişkenleri açısından ögretmen görüşleri arasında anlamlı bir fark yoktur. Cinsiyet ve daha önce destekten yararlanma durumuna göre birkaç maddede görüş ayrılıkları tespit edilmiştir. Öte yandan, yaş, kıdem ve okul türü değişkenleri ise pek çok maddede öğretmenlerin görüşleri arasında anlamlı farklılık oluşturmaktadır. Genç, kıdemi düşük ve özel okulda çalışan ögrretmenler öğrenci başına destek konusunda gerekçelendirme, süreç ve uygulama konularında diğerlerine göre daha iyimserdir.

\section{Abstract}

The purpose of this study was to reveal opinions of teachers charged in private and public schools on the government grant for private school students. Teacher opinions on government grant per pupil enrolled in private schools were analyzed in respect to various variables. A total of 119 volunteer teachers who work in Mersin province Mezitli district have participated. Teacher opinions were collected via a data collection tool which contains an information form and a survey. The survey was composed of 26 items. For performing statistical analyses on data, frequencies, percentages, and difference analyses were used. According to results obtained from the analyses, there were no significant difference among teachers' opinions in terms of marital status, degree of graduation and field of instruction. In relation to gender and own or close relative's child's benefits from government support some differences were observed in scores obtained from a few items. On the other hand, age, seniority and school type variables brought up significant differences in teacher opinions on most of the items. Young and less tenured private school teachers have more optimistic opinions concerning justification, processes and implementation of government support per pupil in private schools.
\end{abstract}

\section{Key Word} schools, government support.

$\begin{array}{ll}\text { Atıf için: } & \text { Ergen, H. \& Altıner, T. (2019). Özel Okullarda Öğrenci Başına Devlet Desteği Konusunda } \\ \text { For Citation } & \text { Öğretmen Görüşleri. Muğla Sitkı Koçman Üniversitesi Eğitim Fakültesi [MSKU Journal of }\end{array}$ Education], 6(2), 70-87. DOI:10.21666/muefd.531607

\begin{tabular}{ccc}
\hline Received: 23.02.2019 & Accepted: 28.10.2019 & Published: 01.11.2019 \\
\hline Araştırma Makalesi & & Research Article
\end{tabular}

Eğitim finansmanının temel sorularından birisi harcamaların kamu ve özel kaynaklar tarafindan ne oranda karşılanması gerektiğiyle ilgilidir. Eğitim yarı-kamusal bir mal olarak ele alındığında, hizmetin

\footnotetext{
${ }^{1}$ Mersin Üniversitesi Eğitim Fakültesi, ergen@mersin.edu.tr, ORCID: 0000-0002-2611-1863

${ }^{2}$ Mersin Üniversitesi, EBE, Eğitim Yönetimi TYL, tolgaaltiner1606@gmail.com. ORCID: 0000-0002-9804-0080
} 
sunumuyla ilgili devletin sorumluluğu sunmak, desteklemek ve düzenlemek çerçevesinde ele alınabilir (Belfield, 2000). Hizmetin genel olarak değerlendirilmesi için ise yeterlik, etkinlik ve eşitlik ölçütleri kullanılır (Benson, 1995). Türkiye'de 2014-15 eğitim-öğretim yılından başlamak üzere uygulanan özel öğretim kurumlarında okuyan öğrencilere eğitim ve öğretim desteği uygulaması da bu ölçütler ve sorumluluk alanları çerçevesinde ele alınabilir.

Modernleşmeyle birlikte kitlelere yaygınlaştırılmaya başlayan eğitim-öğretim hizmetleri daha önce büyük ölçüde özeldi. Ulus devletlerin ve kitlesel üretim yapan sanayi tesislerinin ortaya çıkmasıyla birlikte başlayan bu kitleselleşme eğilimi yeni üretim biçiminin okullara uygulanmasıyla sadece arzu edilebilir değil aynı zamanda mümkün olmuştur. Hizmetin sunumunun ucuza gelmesinin yanı sıra ulusal bilince sahip bir işgücünün yetiştirilmesi ulusal ekonominin istikrarı açısından önemli görülmekteydi. $\mathrm{Bu}$ nedenle 20. yüzyılın başından itibaren devlet eğitime daha fazla müdahale etmeye başlamıştır. $\mathrm{Bu}$ müdahaleler okul açma, bu okullara finansman sağlama, öğretmen, yönetici ve uzman personel yetiştirme, müfredat geliştirme, merkezi sınavları yapma, diplomaları tanıma gibi farklı biçimlerde ortaya çıkabilmektedir (Belfield, 2000). Böylece kitlesel eğitim, devletin ücretsiz olarak sunduğu, asgari ve zorunlu, genellikle devlet okullarına gidilerek elde edilen bir hizmet olarak anlaşılmaya başlanmıştır. Eğitim hizmetini devletin sunmasını savunmanın en önemli dayanağı, kuşkusuz, özel sektörün toplumun yoksul, yıpranmış ve dezavantajlı kesimlerine ulaşacak kadar büyük sermaye yatırımını gerçekleştirmesinin güçlügüudür (Belfield, 2000). Diğer gerekçeler ailelerin eşitlik kaygıları, özel ve kamu okullarının kısa/uzun vadeli bakış açıları ve eğitim programlarının hazırlanması, uygulanması ve denetlenmesi süreçlerindeki standardizasyon ihtiyacı olarak sıralanabilir (Ünal, 1996). Ayrıca, arabulucu devlet anlayışının eğitimin, dolayısıyla çocukların geleceğinin farklı çıkar gruplarının ele geçirme savaşına sahne olmasını engelleyeceği varsayılmaktadır.

Ĕgitim hizmetinin devlet tarafından sunulmasının eleştirilen yönlerinin başında ise; devlet okullarının hesap verebilirliğinin ve iflas etme riskinin bulunmaması gelir. Böylece düşük kaliteli eğitim sunan okullar piyasadan çekilmek zorunda kalmaz ve hizmete devam eder (Belfield, 2000). Kaliteli hizmet sunan devlet okullarının ise talep yaratma kapasitesi yoktur ve sınırlı sayıda vatandaşa hizmet eder. Devlet okullarının eleştirildiği bir başka husus da veli tercihleri doğrultusunda esnek hizmet sunma konusundaki yetersizlikleridir (Bray, 1996).

Günümüzde gelişmiş ülkelerde finansman yöntemine göre üç tür okul bulunur: devlet okulu, özel okul ve devlet destekli özel okul. Devlet okullarının harcamaları vergi gelirlerinden finanse edilir, veliler kişisel harcamaları karşılar, bazen küçük bir katkı payı alınır. Özel okullar ise aile geliri, burs fonları ve kredi kaynaklarından finanse edilir; devlet bu okulların sadece denetiminden sorumludur (Cooms ve Hallak, 1987). Devlet destekli okullar ise daha yeni bir uygulamadır: devlet eğitim hizmetini doğrudan sunmak yerine, özel sektörü destekleyerek eğitim hizmeti vermeye teşvik eder, böylece hizmetin sunumuyla ilgili bir takım yükleri devretmiş olur. Ancak, özel okulların devlet tarafından desteklenmesi fikrinin altında, rekabet sonucu kalitenin artırılabileceği düşüncesi vardır.

Özel okulların desteklenmesinin gerekçelerinden bir tanesi eğitim hizmetinin yeterliğiyle ilgilidir. Devlet yeterince kaliteli eğitim hizmeti sunulduğundan emin olmalıdır ve bunun için kaliteli özel okulları destekleyerek arz yaratma yolunu seçebilir. Böylece hizmetin etkinliğini de artırabilir. Bu görüsse göre, esasen, kaliteli eğitim hizmetinin faydalarının elde edilmesiyle hizmeti kamu ya da özel sektörün sunması arasında bir ilişki yoktur; devlet verimli çalışan okulları desteklemelidir (Belfield, 2006). Öte yandan, uygun devlet desteğinin nasıl olacağına ilişkin bir ölçütün bulunması gerekir. Devlet bu nedenle, yeterlik ve etkinlik ölçütlerinin yanı sıra eşitlik ölçütünü de gözetmelidir (Kurul, 2012). Devlet nasıl bir destek sağlayacağıyla ilgili olarak eğitimin sosyal ve bireysel getiri oranlarına, eğitimin ulusal ekonomideki payına, kamu kaynaklarından ayrılan eğitim bütçesinin büyüklügüne vb. bakarak bir tercihte bulunabilir (Woodhall, 2004).

Özel okullar Avrupa'da devlet tarafindan öğrenci başına doğrudan destek, vergi indirimi gibi yollarla desteklenmektedir (Eurydice, 2014). ABD'de ise bazı devletler kupon [voucher] sistemiyle, velilere devletin sunduğu ortalama okul maliyetini çek olarak vermekte ve özel okullara bu kuponlanı bozma garantisi vermektedir (Sutton \& King, 2013). ABD’deki diğer bazı devletler ise sözleşmeli okullar [charter schools] emlak vergisi gelirlerinden finanse etmektedir (Bifulco \& Reback, 2014). Genel olarak özel okullara devlet desteğinin dört değişik formundan bahsedilebilir: vergi indirimi, yatırım teşviki, doğrudan destek ve öğrenci başına destek. Türkiye'de bu dört destek türünden ilk üçü Milli Eğitim Bakanlığı'na (MEB) bağlı özel öğretim kurumları ile vakıf yükseköğretim kurumları çerçevesinde 
1980'lerden bu yana kullanılmaktadır. MEB'e bağlı özel öğretim kurumlarında okuyan öğrenci başına destek verilmesi ise görece yeni bir uygulamadır.

Türkiye'de, 2012'de yayımlanan Milli Eğitim Bakanlı̆̆1 (MEB) Özel Öğretim Kurumları Yönetmeliği'ne (ÖÖKY; MEB, 2012) yapılan ek ve değişikliklerle örgün eğitim yapan özel okullarda okuyan öğrenciler için bir eğitim ve öğretim desteği verilmesinin yolu açılmıştır. Eğitim ve öğretim desteğinin uygulanmasına 2014-15 eğitim ve öğretim yılı itibariyle başlanmıştır. Hedeflenen destek verilecek ögrenci sayıları ve destek tutarları Tablo 1'de görülmektedir.

Tablo 1

Özel Öğretimde İlk Defa Destek Sağlanan Öğrenci Sayıları ve Destek Tutarları

\begin{tabular}{|c|c|c|c|c|c|c|c|c|c|c|}
\hline & \multicolumn{2}{|c|}{ Okul öncesi } & \multicolumn{2}{|c|}{ İlkokul } & \multicolumn{2}{|c|}{ Ortaokul } & \multicolumn{2}{|c|}{ Lise } & \multicolumn{2}{|c|}{ Temel lise } \\
\hline & $n$ & $E$ & $n$ & $E$ & $n$ & $E$ & $n$ & $E$ & $n$ & $E$ \\
\hline 2014-15 & 27.938 & 2.500 & 47.627 & 3.000 & 54.908 & 3.500 & $75.000^{*}$ & 3.500 & ** & 3.000 \\
\hline 2015-16 & 20.000 & 2.680 & 50.000 & 3.220 & 50.000 & 3.750 & $110.000 *$ & 3.750 & $* *$ & 3.220 \\
\hline $2016-17$ & 5.831 & 2.860 & 82.279 & 3.440 & 84.850 & 4.000 & 73.291 & 4.000 & 69.465 & 3.440 \\
\hline $2017-18$ & 6.000 & 3.060 & 15.000 & 3.680 & 15.000 & 4.280 & 15.000 & 4.280 & 24.000 & 3.680 \\
\hline 2018-19 & 6.000 & 3.290 & 15.000 & 3.960 & 15.000 & 4.610 & 15.000 & 4.610 & 24.000 & 3.960 \\
\hline
\end{tabular}

Kaynak: MEB (2014-2017); MEB (2018). Not: * temel lise dâhil; ** lise içinde.

MEB özel okullarda okuyan öğrencilere yapılan desteği belirlerken destek sağlanacak öğrenci sayısını il bazında belirlemektedir. Bu sayılar ve destek sağlanacak öğrenciler belirlenirken; kalkınmada öncelik derecesi, aile gelir düzeyi, öğrenci sayısı öğrenci ve okulun başarı seviyeleri ile öncelikli öğrenciler gibi ölçütler kullanıldığı belirtilmektedir (MEB, 2017). Bu kapsamda; 2014-15'te 250.000 öğrenciye destek sağlanması planlanırken 166.563 öğrenciye 532.832.625 TL ödeme yapılmıştır. Destek sağlanan öğrenci sayıs1 2015-16'da 337.375, sağlanan destek tutar1 1.160.534.862 TL; 2016-17'de 313.324 öğrenciye 1.166.335.768 TL tutarında gerçekleşmiştir. (MEB, 2016; 2017). 2017-18 ve 2018-19'da ise ilaveten destek sağlanacak öğrenci sayısı her yıl için 75.000 olarak belirlenmiştir (MEB, 2017). Bakan tarafindan 2017-18'de toplam 301.777 öğrenciye 1.207.708.478 TL eğitim ve öğretim desteği yapıldığ1; 2018-19'da toplam 253.827 öğrencinin bu destekten yararlanmasının planlandığı; önümüzdeki süreçte uygulamanın kademeli olarak kaldırılacağı açıklanmıştır (Milli Eğitim Bakanının TBMM Plan ve Bütçe Komisyonunda Milli Eğitim Bakanlığının bütçesi konuşulurken yaptığı sunuştan; TBMM, 2018, s. 12). Buna göre; 2019-20'den itibaren ilk defa destek sağlanacak öğrenci sayıları sıfirlanacak, destek almaya devam eden öğrenciler, bulundukları eğitim kademelerini tamamlayana kadar destekten yararlanmaya devam edecektir. Bu destek için ayrılan kaynağın devlet okullarının niteliğinin iyileştirilmesi için kullanılması anlayışı ifade edilmiştir. Özel okullara sağlanan desteğin veli tercihlerini ne ölçüde etkilediği tartışma konusudur. Veli tercihlerini etkileyen başat faktör devlet okullarının niteliği olabilir. Bakanın bu yaklaşımı ise, ilk bakışta, aynı sunumda yer alan özel öğretim alanının desteklenmesi ve geliştirilmesi yaklaşımıyla çelişir gibi görünmektedir. Ancak, buradan elde edilebilecek bir çıkarım, özel öğretimin başka yöntemlerle desteklenmeye devam edeceği yönündedir.

MEB'in sağladığı destek özel okul ücretleri ile karşılaştırıldığında; öğrenim ücretinin \%10'u ila \%30'u arasında bir yerde gerçekleşmiştir. Öte yandan; bu destek öğrenci başına yapılan harcamalarla da karşılaştırılabilir. TÜiIK tarafından hesaplanan eğitim kademelerine göre öğrenci başına harcamalar Tablo 2'de görülmektedir. Bu harcamalar devlet, özel sektör ve uluslararası kaynaklardan sağlanan toplam harcamaların öğrenci sayısına bölünmesiyle elde edilmektedir. Toplam harcamaların kamu ve özel sektöre düssen payları da tablonun son iki sütununda yer almaktadır. Kademelere göre ele alındığında özel harcamaların payı 2017 'de en yüksek liselerde $(\% 38,5)$, en düşük ilkokullarda $(\% 25,8)$ gerçekleşmiştir. Bu oran okul öncesi eğitimde \%30, ortaokullarda ise \%29 civarındadır. 
Tablo 2

Öğrenci Başına Eğitim Harcamaları ile Kamu ve Özel Kaynakların Payları

\begin{tabular}{|c|c|c|c|c|c|c|c|c|c|c|}
\hline & \multicolumn{2}{|c|}{ Okul öncesi } & \multicolumn{2}{|c|}{ İlkokul } & \multicolumn{2}{|c|}{ Ortaokul } & \multicolumn{2}{|c|}{ Lise } & Kamu & Özel \\
\hline & $E$ & $\$$ & $E$ & $\$$ & $E$ & $\$$ & $E$ & $\$$ & $\%$ & $\%$ \\
\hline 2011 & 3.528 & 2.103 & 2.631 & 1.568 & 2.754 & 1.641 & 3.838 & 2.287 & 76,72 & 27,88 \\
\hline 2012 & 4.461 & 2.477 & 3.229 & 1.793 & 3.229 & 1.771 & 4.532 & 2.516 & 74,57 & 30,11 \\
\hline 2013 & 4.980 & 2.614 & 3.646 & 1.914 & 3.646 & 1.844 & 5.104 & 2.679 & 74,71 & 29,74 \\
\hline 2014 & 5.893 & 2.689 & 4.288 & 1.956 & 4.288 & 1.926 & 5.453 & 2.488 & 73,87 & 30,54 \\
\hline 2015 & 6.078 & 2.231 & 4.736 & 1.738 & 4.736 & 1.698 & 6.075 & 2.229 & 75,13 & 29,69 \\
\hline 2016 & 7.062 & 2.333 & 5.505 & 1.819 & 5.505 & 1.840 & 7.256 & 2.397 & 75,62 & 29,84 \\
\hline 2017 & 7.328 & 2.005 & 5.782 & 1.582 & 5.782 & 1.600 & 8.750 & 2.385 & 74,52 & 31,19 \\
\hline
\end{tabular}

Kaynak: TÜİK (2018).

MEB'in sağladığı destek öğrenci başına harcamalarla karşılaştırıldığında 2017 için; okul öncesi eğitimde \%42; ilkokullarda \%64; ortaokullarda \%73; liselerde ise \%49 düzeyindedir. Buna göre kamunun özel okullara sağladığı desteğin ortaokul kademesinde öğrenci başına kamu harcamalarında görece fazla, diğer kademelerde ise düşük olduğu sonucuna varılabilir. Sağlanan destek sonrası özel okullardaki öğrenci sayılarında önemli oranda artış meydana gelmiştir. Özel öğretimde okuyan öğrencilerin kademelerindeki toplam kayıtlı öğrenci sayısına oranlarında 2012'den bu yana meydana gelen değişiklikler Şekil 1'de görülmektedir.

Şekil 1'e göre; dönem içinde özel okullarının öğrenci sayısındaki payının en çok arttığı kademe ortaöğretim olmuştur. Ortaöğretimde özel okulların payı 2012'deki \%3,14 seviyesinden 2017'de \%9,84 seviyesine ulaşmıştır. Bunda temel liselerin payı da vardır. Paylardaki ikinci büyük artış ise ortaokul kademesinde görülmüştür. Ortaokullarda özel öğretimin payı 2012'de \%2,99 iken, $2017 \% 4,58$ 'e yükselmiştir. Sayı olarak bakıldığında özel ortaokullarda okuyan öğrencilerin toplamı 2012'de 164.294 iken 2017'de 321.779'dur. Bunun 148.610'unu kız, 173.169'unu erkek öğrenciler oluşturmaktadır.

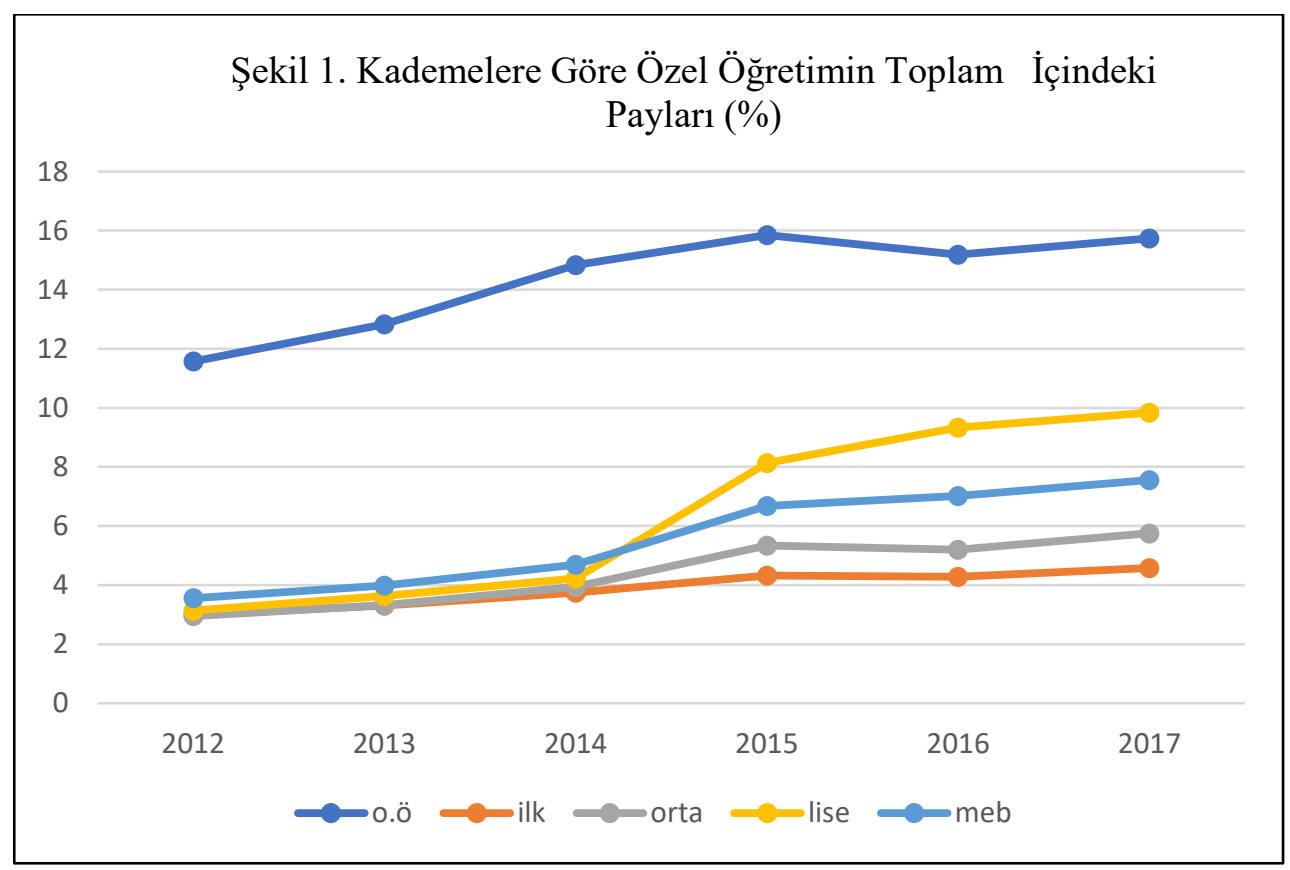

Şekil 1. Kademelere göre özel öğretimin toplam içindeki payları (\%). Özel okullarda okuyan öğrenci sayılarının toplam öğrenci sayısına oranı (\%) olarak MEB verileri kullanılarak oluşturulmuştur. Kaynak: MEB, 2013-2018, Milli Eğitim İstatistikleri, MEB ve TÜIKK: Ankara.

\section{Özel Öğretimin Desteklenmesine Yönelik Yaklaşımlar}


Türkiye'de özel okulların desteklenmesiyle ilgili literatür, yaklaşımlarına göre liberal ve eleştirel olarak çerçevelendirilebilir. Liberal yaklaşım, özel okulların desteklenmesini eğitim hizmetinin etkinliğinin artırılması ve öğrenci-veli tercihlerinde özgürleşme çerçevesinde tartışmaktadır. Eleştirel yaklaşımlar ise; konuyu eğitimin piyasalaşması, öğrencinin müşterileşmesi ve toplumun neo-liberal bir anlayışla dönüştürülme çabası olarak ele almaktadır.

Liberal yaklaşıma göre Türkiye'de eğitime devlet müdahalesini destekleyecek bulgular sınırlıdır. Bu tartışma büyük ölçüde Friedman'ın (1955/2002) eğitimde devletin rolüyle ilgili özgün yazısına dayanmaktadır Araştırmalardan elde edilen eğitimin dışsallıklarıyla ilgili bulgular belirsiz, gelir dağılımı adaletiyle ilgili bulgular ise ters yöndedir (Çokgezen ve Terzi, 2008). Devlet okullarında birim öğrenci maliyeti düşük çıkmakla birlikte, özel okulların daha etkin çalıştığı, devlet okullarına devam eden öğrenciler açısından ise açığın kurs vb. okul dışı telafi edici araçlarla giderilmeye çalışıldığına ilişkin bulgular vardır. Özel okulların desteklenmesinin alt gelir gruplarının kaliteli eğitime ulaşması açsından büyük önemi yönünde görüşler de mevcuttur (Kalkan, 2014). Özel liselerin 1990'lı yıllarda öğrencileri yükseköğretime yerleştirme konusundaki başarısının ortalamanın üzerinde olduğu gözlenmiştir (Kulaksızoğlu, Çakar ve Dilmaç, 1999a). Buna paralel olarak, velilerin özel okullara karşı tutumlarının olumlu olduğu bulgusu da elde edilmiştir (Kulaksızoğlu vd., 1999b). Özel okulların tarihçesinin anlatıldığı bir çalışmada Türkiye'de veliler açısından özel okulların hep gözde okullar olduğu sonucuna varılmıştır (Uygun, 2003).

Devlet ve özel ilköğretim okullarının etkililiğinin araştırıldığı bir çalışmada, özel okulların öğretmen görüşlerine göre, çalışmada ele alınan boyutlarda devlet okullarıyla karşılaştırıldığında daha etkili olduğu sonucuna varılmıştır (Arslan, Satıcı ve Kuru, 2006). Özel okullarda çalışan İngilizce öğretmenlerinin devlet okullarında çalışan meslektaşlarına oranla mesleki gelişime daha çok önem verdikleri gözlenmiştir (Babanoğlu ve Yardımc1, 2017). Özel okullarda öğretmenlerin hesap verebilirliklerinin geliştirilmesinin önemi de vurgulanmıştır (Türkoğlu ve Aypay, 2015). Özel okullarda çalışan okul müdürlerinin devlet okullarında çalışan müdürlere göre öğretim liderliği ile ilgili anketteki görüşlere daha fazla katıldığı, ancak nitel verilerin tersi yönde olduğu bulgusu ifade edilmiştir (Bellibaş ve Gedik, 2014). Temel eğitimde 4+4+4 uygulamasına geçiş sürecinde özel okul öğretmenlerinin daha az sorun yaşadıkları gözlenmiştir (Boz ve Yıldırım, 2014). Araştırma sonuçları ve veli tercihleri doğrultusunda özel öğretime verilen destek artmakta, buna paralel olarak da özel okulların sistem içindeki payı artmaktadır (Özdemir \& Tüysüz, 2017).

Eleştirel yaklaşıma göre; neo-liberalizm devletin kamusal alandaki görevlerini sınırlandırmayı öngördüğünden eğitim politikalarında devletin belirleyiciliğini sınırlandırmaktadır. Aslında neoliberalizm toplumun bütün alanlarını, bu arada toplumu dönüştürmede önemli bir araç olan eğitim alanını ele geçirmek için (kupon, charter okullar, teşvik vb.) bir takım taktikler geliştirmektedir (Şimşek, 2018). Eğitim politikaları sermayenin güç alanına kaydırılmakta, neo-liberalizmin yayılması ile devlet, piyasa ve toplumun eğitimdeki rolleri yeniden sorgulanmaya başlanmaktadır. Eğitimin ekonomik ilgilerle ele alınması sosyal adalet tartışmalarını da arttırmaktadır (Şentürk, 2008). Eğitimin paralı olmas1 yönündeki önermelerin temelinde yatan "faydalanan öder" mantığına göre eğitim "bireysel olanla toplumsal olanın kesiştiği" bir alan olarak değil; tamamen bireysel bir olgu olarak tanımlanmaktadır (Çam, 2006). Eğitimde kamu hizmeti, öncelikle "eğitime katkı payı" uygulamasıyla; özel sermaye kesimlerinin doğrudan okul işletmeciliğine girmek üzere desteklenmesiyle; eğitim hizmetlerinin kantin, taşıma, temizlik işleri, ders kitapları sağlama gibi temel destek alanlarında ticarileştirilmesiyle devlet alanından çıkarak piyasa sistemine açılmaktadır (Çam, 2006).

Aydoğan (2008) özelleştirmenin eğitim üzerindeki etkisini; Türkiye'nin 1998'de onayladığı GATS anlaşmasının gereği olarak kamu hizmetlerinin "yeniden yapılanma" anlayışı çerçevesinde biçimlendirilmesi, bu yolla uluslararası kapitalist sistemle bütünleşmesi şeklinde açıklamaktadır. Kamu eğitiminin özelleştirilmesi ve okul dışı sınava hazırlık faaliyetlerinin yaygınlaştırılması; eğitimin taşeronlaştırılmasının ve öğretmen emeğinin dönüşümünün somut araçları olarak görülmektedir (Keskin Demirer, 2012). Toplumsal sorumluluk sahibi ve içten denetimli öğretmen kimliği yerine, dışsal ölçütlerle kontrol edilen bir öğretmen kimliği oluşturularak öğretmenlik mesleği dönüştürülmeye çalışılmaktadır. Bu süreç eğitim sisteminin tümündeki dönüşümle bir bütün olarak alınmalıdır (Ünal, 2005). Eğitim sisteminin hem içerik, hem de örgütsel işleyiş açısından "işletmeci" bir mantıkla ele alınmasının, herkese eşit ve parasız eğitim hakkından hızla uzaklaşılmasını ve eğitimin planlı bir şekilde piyasa ilişkileri içine çekilerek ticarileştirilmesini beraberinde getirmektedir (Eğitim-Sen, 2015). Okul eğitiminin öğrencilerin öğrenme ihtiyacına odaklı, dayanışmacı, uzun vadeli, teori ve pratiği 
dengelemesi gereken bir eğitim olması gerekirken, tamamen kar amaçlı, kısa vadeli çalışan, sürekli rekabetin kışkırtıldığı ve eğitimin değerinin sınavlarda daha çok soru yapılmasına indirgendiği bir eğitim anlayışına dönüştüğü ifade edilmektedir (Eğitim-Sen, 2015).

Türkiye'de 2014'te alınan dershanelerin kapatılması kararını takiben, bu kapsamda yer alan özel öğretim kurumlarına bir geçiş süresi tanınarak, kurumların temel liselere dönüşmesi veya doğrudan özel okul olarak faaliyet göstermesi için Özel Öğretim Kurumları Standartları'nda belirli esneklikler sağlanmakta ve bu kapsamda teşvikler oluşturulmaktadır (TEDMEM, 2015). Teşvik ve destek uygulaması, eğitimde özel teşebbüslerin teşvik edilmesi politikalarının bir yansımasıdır (TEDMEM, 2016). TEDMEM (2016) eğitim değerlendirme raporuna göre dershanelerin kapatılmasına dair alınan kararlar ile takip eden süreç ve düzenlemeler, özel teşebbüsü destekleme politikalarının daha hızlı bir şekilde ilerlemesine neden olduğundan, bu noktada tartışılması gereken iki konu ön plana çıkmaktadır. (1) Eğitimde özel teşebbüsün desteklenmesi sürecindeki kaynak kullanımına ilişkin esaslar ile bir kamu hizmeti olarak her öğrenci için parasız ve nitelikli eğitimin sağlanması. (2) özel öğretim kurumları, temel liseler ve özel öğretim kurslarının eğitime ve eğitim sistemine olan etkileri. Dershanelerin örgün eğitim kurumlarına dönüşümüne ilişkin okul yöneticileri ile yapılan bir çalışmada, bu dönüşümün uygun olmadığını ifade eden görüşlere sıkça rastlanmakta ve uygun olmadığı savunulan hususlar arasında altyapı yetersizliği, rant oluşturacağı, fiziki yapı yetersizliği, eğitimde kaliteyi düşüreceği yönündeki görüşlerinin belirtildiği görülmektedir (Özan, Polat, Gündüzalp ve Yaraş, 2015). Dershanelerin kapatılması tartışmalarının başladığı ve dönüşümün hayata geçirildiği son dört yılda, Türkiye'deki özel okul oranının tüm kademelerde belirgin ve düzenli bir şekilde artmış olduğu görülmektedir (TEDMEM, 2016). Çam'a (2006) göre; uygulanan neoliberal eğitim politikalarıyla birlikte eğitim bir hak olmaktan çıkmakta, alınıp satılabilen bir meta haline dönüşerek, hem gelir dağılımında meydana gelen bozulmalar hem de kamu harcamalarının bu politikalarla birlikte azaltılması eğitim hakkına çift taraflı zarar vermektedir.

MEB eğitim ve öğretim desteği uygulamasıyla öncelikle kapasite artışını hedeflemektedir. $\mathrm{Bu}$ uygulamayla devlet okullarındaki ikili eğitim yükünün ve derslik başına düşen öğrenci sayısının azaltılacağı vurgulanmaktadır (MEB, 2017). Kalite odaklı rekabet ortamının oluşturulması, isteyenlerin özel okul olanaklarından yararlanabilmesi ve özel sektör yatırımlarının özendirilmesi diğer amaçlar arasındadır (MEB, 2017). Özellikle zorunlu eğitim kademeleri için, özel okullarda okuyan öğrenci velilerinin de ödedikleri vergilerle sağlanan eğitim hizmetinden pay alma talepleri, günümüzde pek çok ülkede, özel okullara sağlanan devlet desteğinin gerekçeleri arasındadır. Bu konuda, veli ve öğrenci görüşlerinin yanı sıra öğretmenlerin de ne düşündükleri önemli olabilir. Özel okullara öğrenci başına destek uygulamasının gerekçeleri özel okulların ve devlet okullarının öğrenciye sunduğu olanaklarla ilişkilendirildiğinde; öğretmen motivasyonunu etkileyecek örgütsel faktörler de ortaya çıkabilir. Ayrıca, uygulamanın yerindeliğinin yanı sıra sürecin etkililiği ile ilgili öğretmenlerin görüşleri de yol gösterici olabilir.

$\mathrm{Bu}$ araştırmada, kamu ve özel okullarda çalışan öğretmenlerin özel okul öğrencilerine yapılan öğrenci başına devlet desteği konusundaki görüşlerinin ortaya konması amaçlanmıştır. Bu amaç doğrultusunda; 1- Öğretmenlerin özel okullara verilen desteği bu okullarda verilen eğitimin kalitesini göz önüne alarak ne derece olumlu bulduklar1;

2- Öğretmenlerin özel okullara verilen desteği devlet okullarında verilen eğitimin kalitesini göz önüne alarak ne derece olumlu bulduklar1;

3- Öğretmenlerin özel okullarda öğrenci başına devlet desteği verilmesi süreciyle ilgili çeşitli konulardaki görüşlerinin de düzeyde olduğu

sorularına cevap bulunmaya çalışılmıştır.

\section{Yöntem}

$\mathrm{Bu}$ çalışmada, tarama yöntemiyle veri toplanması ve analizini içeren bir yöntem kullanılmaktadır. Yapılan çalışma, seçilen okullardaki öğretmenlere 26 soru maddesinden oluşan bir anket uygulaması ile öğretmenlerin, özel okul ögrencilerine devlet desteği ile ilgili görüşlerini elde etmeyi ve betimlemeyi hedeflemektedir.

\section{Çalışma Grubu}

Araştırmanın evrenini 2017-18 eğitim-öğretim yılında Mersin ili Mezitli ilçesinde kamu ve özel öğretim ortaokullarında görev yapan öğretmenler oluşturmaktadır. Mersin ili nüfus yoğunluğu açısından Türkiye 
ortalamasının üzerinde nüfusu olan bir ildir. Dolayısıyla öğrenci sayısı da yeterince yüksek olan bir ildir. Mersin ilinin merkez ilçelerinden biri olan Mezitli ilçesi de öğrenci sayısı fazla olan bir ilçedir. Mezitli ilçesinde 2018 yılı itibariyle 95 okul ve bu okullarda 1.477 derslik, 35.852 öğrenci ve 1.954 öğretmen bulunmaktadır. İlkokul ve ortaokullarda derslik başına düşen öğrenci sayısı 29'dur (Mezitli MEM, 2018). Mezitli ilçesindeki devlet okulu ve özel okul sayıs1 ve bu okullarda çalışan öğretmen sayıs1 çalışmayı yapmaya uygun olduğu için bu çalışma Mezitli İlçesinde yürütülmüştür. Araştırmanın çalışma grubu amaçlı örneklem oluşturacak şekilde seçilmiştir. Araştırmanın çalışma grubunu Mersin ili Mezitli ilçesinde yer alan üç kamu ortaokulu ve iki özel ortaokulda görev yapan branş öğretmenleri oluşturmaktadır. Bu okullar; Şehit Fatih Soydan Ortaokulu, Muhittin Develi Ortaokulu, Davultepe Atatürk Ortaokulu, Sinav Koleji Ortaokulu ve Kültür Koleji Ortaokulu olarak belirlenmiştir. Araştırmaya bulunabilirlik esasına göre 119 öğretmen katılmıştır. Dolayısıyla öğretmenlerden elde edilen görüşlerin ancak çalışma grubundaki okulları temsil ettiği iddia edilebilir. Çalışma grubunun karakteristiklerine ilişkin istatistiki bilgiler Tablo 3'te yer almaktadır.

Tablo 3 Araştırmaya Katılan Öğretmenlerin Demografik Dă̆llımı

\begin{tabular}{|c|c|c|c|c|c|c|c|}
\hline \multirow{2}{*}{ Özellikler } & \multirow{2}{*}{ Kategori } & \multicolumn{2}{|c|}{ Kamu } & \multicolumn{2}{|c|}{ Özel } & \multicolumn{2}{|c|}{ Toplam } \\
\hline & & $f$ & $\%$ & $f$ & $\%$ & $f$ & $\%$ \\
\hline \multirow{2}{*}{ Cinsiyet } & Kadın & 43 & 62,3 & 33 & 66,0 & 76 & 63,9 \\
\hline & Erkek & 26 & 37,7 & 17 & 34,0 & 43 & 36,1 \\
\hline \multirow{2}{*}{$\begin{array}{l}\text { Medeni } \\
\text { durum }\end{array}$} & Evli & 59 & 85,5 & 30 & 60,0 & 89 & 74,8 \\
\hline & Bekâr & 10 & 14,5 & 20 & 40,0 & 30 & 25,2 \\
\hline \multirow{3}{*}{$\begin{array}{l}\text { Lisans } \\
\text { ĕğitimi }\end{array}$} & Ĕgitim fakültesi & 51 & 73,9 & 33 & 66,0 & 84 & 70,6 \\
\hline & Diğer fakülteler & 13 & 18,8 & 12 & 24,0 & 25 & 21,0 \\
\hline & Yüksek lisans & 5 & 7,2 & 5 & 10,0 & 10 & 8,4 \\
\hline \multirow{4}{*}{ Yaş } & $20-30$ & 4 & 5,8 & 25 & 50,0 & 29 & 24,4 \\
\hline & $31-40$ & 37 & 53,6 & 18 & 36,0 & 55 & 46,2 \\
\hline & $41-50$ & 26 & 37,7 & 4 & 8,0 & 30 & 25,2 \\
\hline & $51+$ & 2 & 2,9 & 3 & 6,0 & 5 & 4,2 \\
\hline \multirow{5}{*}{$\begin{array}{l}\text { Mesleki } \\
\text { kudem }\end{array}$} & $1-5$ & 1 & 1,4 & 29 & 58,0 & 30 & 25,2 \\
\hline & $6-10$ & 8 & 11,6 & 10 & 20,0 & 18 & 15,1 \\
\hline & $11-15$ & 21 & 30,4 & 5 & 10,0 & 26 & 21,8 \\
\hline & $16-20$ & 21 & 30,4 & 1 & 2,0 & 22 & 18,5 \\
\hline & $21+$ & 18 & 26,1 & 5 & 10,0 & 23 & 19,3 \\
\hline \multirow{2}{*}{ Okul türü } & Кати & 69 & 100,0 & 0 & 0,0 & 69 & 58,0 \\
\hline & Özel & 0 & 0,0 & 50 & 100,0 & 50 & 42,0 \\
\hline \multirow{13}{*}{ Branş } & Matematik & 10 & 14,5 & 10 & 20,0 & 20 & 16,8 \\
\hline & Fen Bilimleri & 13 & 18,8 & 5 & 10,0 & 18 & 15,1 \\
\hline & Türkçe & 14 & 20,3 & 7 & 14,0 & 21 & 17,6 \\
\hline & Sosyal Bilgiler & 7 & 10,1 & 5 & 10,0 & 12 & 10,1 \\
\hline & Din Kültürü ve Ahlak Bilgisi & 1 & 1,4 & 1 & 2,0 & 2 & 1,7 \\
\hline & Ingilizce & 11 & 15,9 & 11 & 22,0 & 22 & 18,5 \\
\hline & Müzik & 2 & 2,9 & 2 & 4,0 & 4 & 3,4 \\
\hline & Beden Ĕgitimi & 0 & 0,0 & 4 & 8,0 & 4 & 3,4 \\
\hline & Görsel Sanatlar & 2 & 2,9 & 1 & 2,0 & 3 & 2,5 \\
\hline & Rehberlik & 1 & 1,4 & 3 & 6,0 & 4 & 3,4 \\
\hline & Özel Ĕ̈itim & 3 & 4,3 & 0 & 0,0 & 3 & 2,5 \\
\hline & Teknoloji ve Tasarım & 2 & 2,9 & 1 & 2,0 & 3 & 2,5 \\
\hline & Bilişim Teknolojileri & 3 & 4,3 & 0 & 0,0 & 3 & 2,5 \\
\hline
\end{tabular}

$n=119$

\section{Verilerin Toplanması}

Araştırmanın kuramsal temelini oluşturabilmek, araştırmayı belirlenen amaçlara ulaştırabilmek ve uygun veri toplama aracını geliştirebilmek için ilgili alanyazın taraması yapılmıştır. Araştırma için geliştirilen anketi oluşturmak adına çeşitli kamu ve devlet okullarında görev yapan öğretmenlerle görüşülerek ön anket maddeleri oluşturulmuştur. Bu taslak üzerinde çalışılarak 5'li Likert tipi ölçek şeklinde 26 soru maddesinden oluşan, Özel Okul Öğrencilerine Devlet Desteği Konusunda Öğretmen 
Görüşleri başlıklı bir anket formu oluşturulmuştur. Anket için güvenirlik ve yapı geçerliği çalışması yapılmamış ancak kapsam geçerliğini sağlayabilmek amacıyla Mersin Üniversitesi Eğitim Bilimleri Bölümünde görevli alanında uzman üç öğretim üyesinin görüşü alınarak anket formu uygulanmaya hazır hale getirilmiştir.

Veri toplama aracı bir kişisel bilgi formu ve üç bölüme ayrılmış bir anket olmak üzere iki kısımdan oluşmaktadır. Anketin birinci ve ikinci bölümleri öğrenci başına desteğin uygun görülüp görülmemesiyle ilgilidir. Birinci bölümde özel okulların üstünlükleri, ikinci bölümde devlet okullarının zayıf yönleri gerekçe gösterilerek özel öğretim desteğinin uygunluğu sorulmuştur. Bu sorulardan elde edilen yanıtlarla öğretmen görüşlerinin liberal ve eleştirel finansman yaklaşımlarından hangisini daha fazla desteklediğine ilişkin bir sonuç elde edilebileceği düşünülmektedir. Zira liberal görüş daha ziyade özel öğretimi desteklerken, eleştirel görüş devletin bu hizmeti sunmasını önemsemektedir. Üçüncü bölümde ise; genel olarak öğrenci başına destek süreci ile ilgili görüşlere yer verilmiştir. Öğretmenlerin ifade etmek istedikleri diğer hususlar bu bölümün sonunda yer alan açık uçlu bir soruyla sorulmuştur.

Anket uygulanmadan önce Mersin Üniversitesindeki yetkili mercilerden ve Mersin İl Milli Eğitim Müdürlüğü'nden gerekli izinler alınarak 2017-18 eğitim öğretim yılının Mart ayı içerisinde Mezitli ilçesinde bulunan beş ortaokula anketler öğretmenlere elden birebir görüşülerek teslim edilmiştir. Mart ayı içerisinde 15 günlük süre içerisinde 119 öğretmene uygulanıp hepsinden de eksiksiz bir şekilde geçerli süre içerisinde toplanmıştır.

\section{Verilerin Analizi}

Araştırmanın amaçları doğrultusunda hazırlanan anket formuyla toplanan veriler üzerinde istatistiksel çözümlemelerin yapılabilmesi için SPSS 20.0 paket programı kullanılmış, verilerin analizinde frekans, yüzde, t-testi, tek yönlü varyans analizi (ANOVA) ve yeterli gözlem olmayan durumlarda bu testlerin parametrik olmayan karşılıkları kullanılmıştır. Katılımcıların görüşleri arasında anlamlı farklılık olup olmadığı $\mathrm{p}=0,05$ seviyesinde test edilmiştir. Öğretmen görüşleri arasında fark olup olmadığına yönelik olarak; bağımsız değişkenlerden cinsiyet, medeni durum ve okul türüne ilişkin analizler t-testi ile yaş, kıdem, branş ve eğitim durumuna ilişkin analizler ise ANOVA ile yapılmıştır.

Anketten elde edilen puanlar şu kriterlere göre yorumlanmıştır: (a) 1-1,49 arası "hiç katılmıyorum"; (b) 1,5-2,49 aras1 "katılmıyorum"; (c) 2,5-3,49 aras1 "kararsızım"; (d) 3,5-4,49 aras1 "kat1lıyorum"; (e) 4,55 aras1 "tamamen kat1lyyorum".

\section{Bulgular}

$\mathrm{Bu}$ bölümde çalışmada öğretmenlere uygulanan anket maddelerine ilişkin toplanan verilerin analiz edilmesi sonucunda elde edilen bulgular yer almaktadır. Tablo 4'te öğretmenlerin anketin maddelerine verdikleri cevaplara ait puan ortalamaları ve standart sapmaları görülmektedir.

Tablo 4 incelendiğinde; çalışma grubunda yer alan öğretmenlerin katıldıkları maddeler M2, M3, M4, M5 ve M7 ile sınırlıdır. Buna göre öğretmenlerin ortalama görüşü özel okullardaki fiziksel şartların iyi, öğrenci sayısının az, ders dışı etkinliklerin fazla, yabancı dil eğitimin ve rehberlik hizmetinin daha iyi olduğuna yöneliktir. Öte yandan öğretmenler M16 ve M23'te yer alan görüşlere katılmamaktadır. Buna göre öğretmenler ortalama olarak, öğrenci başına destek sağlanan öğrencilerin adil biçimde belirlendiği ve öğrenci başına verilen desteğin fazla olmadığı görüşlerine katılmamaktadır. Anketin geri kalan 20 maddesine ilişkin alınan ortalama puanlar "kararsız" kategoriye düşmektedir. Veriler incelendiğinde öğretmenlerin puanlarının standart sapmalarının yüksek, ortalamaların ise genellikle kararsız olarak ortaya çıktığı gözlenmiştir. Öğretmenlerin kararsız kaldıkları maddelerin özellikle devlet okullarında sunulan eğitimin niteliği ve destek uygulamasının etki alanı ile ilgili olduğu görülmektedir. Bu durum, öğretmenlerin, ortalama olarak, destek uygulamasının gerekliliği konusunda şüphe sahibi olduklarının bir göstergesi olarak yorumlanabilir. 
Tablo 4

Anketin Maddelerine Ait Ortalamalar ve Standart Sapmalar

\begin{tabular}{|c|c|c|}
\hline Maddeler & $\overline{\mathbf{X}}$ & SS \\
\hline \multicolumn{3}{|l|}{ Özel öğretim okullarında öğrenci başına devlet desteği verilmesinin bu okullarda } \\
\hline 1 Öğretim kalitesi daha yüksek olduğu için olumlu olduğunu düşünüyorum. & 3,15 & 1,46 \\
\hline 2 Fiziksel şartlar daha iyi olduğu için olumlu olduğunu düşünüyorum. & 3,70 & 1,28 \\
\hline 3 Öğrenci sayısı daha az olduğu için olumlu olduğunu düşünüyorum. & 3,87 & 1,19 \\
\hline 4 Ders dış1 etkinlikler daha çok olduğu için olumlu olduğunu düşünüyorum. & 3,82 & 1,23 \\
\hline 5 Yabancı dil eğitimi daha iyi yapılddı̆̆ için olumlu olduğunu düşünüyorum. & 3,82 & 1,24 \\
\hline 6 Ölçme-değerlendirme daha iyi yapıldığı için olumlu olduğunu düşünüyorum. & 3,05 & 1,47 \\
\hline 7 Rehberlik hizmetleri daha iyi yapıldığı için olumlu olduğunu düşünüyorum. & 3,57 & 1,36 \\
\hline \multicolumn{3}{|l|}{ Özel öğretim okullarında öğrenci başına devlet desteği verilmesinin devlet okullarında } \\
\hline $\begin{array}{l}8 \\
\text { Öğretim kalitesi daha düşük olduğu için olumlu olduğunu düşünüyorum. }\end{array}$ & 2,57 & 1,50 \\
\hline 9 Fiziksel şartlar daha kötü olduğu için olumlu olduğunu düşünüyorum. & 2,98 & 1,43 \\
\hline 10 Öğrenci sayısı daha çok olduğu için olumlu olduğunu düşünüyorum. & 3,34 & 1,35 \\
\hline 11 Ders dış1 etkinlikler daha az olduğu için olumlu olduğunu düşünüyorum. & 3,19 & 1,42 \\
\hline daha kötü yapıldığ 1 için olumlu olduğunu düşünüyorum. & 3,15 & 1,44 \\
\hline 13 Ölçme-değerlendirme daha kötü yapıldığ̣ için olumlu olduğunu düşünüyorum. & 2,60 & 1,41 \\
\hline 14 Rehberlik hizmetleri daha kötü yapıldığı için olumlu olduğunu düşünüyorum. & 2,70 & 1,34 \\
\hline \multicolumn{3}{|l|}{ Özel öğretim okullarında öğrenci başına devlet desteği verilmesiyle ilgili olarak } \\
\hline 15 Öğrenci başına destek süreciyle ilgili detaylı bilgi sahibiyim. & 2,85 & 1,31 \\
\hline 16 Öğrenci başına destek sağlanan öğrencilerin adil biçimde belirlendiğini düşünüyorum. & 2,25 & 1,16 \\
\hline 17 Öğrenci başına verilen desteğin yeterli düzeyde olduğunu düşünüyorum. & 2,65 & 1,22 \\
\hline 18 Öğrenci başına destek verilmesinin kapsamlı bir uygulama olduğunu düşünüyorum. & 2,90 & 1,25 \\
\hline 19 Öğrenci başına destek verilmesinin adaletli bir uygulama olduğunu düşünüyorum. & 2,65 & 1,26 \\
\hline 20 Öğrenci başına destek sistemine isteyen herkesin başvurabileceğini düşünüyorum. & 3,09 & 1,38 \\
\hline 21 Öğrenci başına destekten ihtiyacı olanların yararlanabileceğini düşünüyorum. & 3,02 & 1,38 \\
\hline 22 Öğrenci başına destek verilmesinin gerekli olduğunu düşünüyorum. & 3,35 & 1,38 \\
\hline 23 Öğrenci başına verilen desteğin fazla olduğunu düșünüyorum. & 2,15 & 1,31 \\
\hline 24 Öğrenci başına destek uygulamasının devlet okullarının kalitesini düşüreceğini düşünüyorum. & 2,55 & 1,46 \\
\hline 25 Öğrenci başına destek uygulamasının özel okulların kalitesini yükselteceğini düşünüyorum. & 2,72 & 1,37 \\
\hline 26 Öğrenci başına destek verilmesinin özel sektörün çıkarına bir uygulama olduğunu düşünüyorum. & 3,42 & 1,42 \\
\hline
\end{tabular}
$\mathrm{n}=119$

Öğretmenler arasında yaşanan görüş ayrılığının kaynağını belirlemek amacıyla, veri toplama aracıyla toplanan verilere dayalı olarak elde edilen değişkenler açısından öğretmen görüşleri arasında istatistiksel açıdan fark oluşup oluşmadığ 1 test edilmiştir. Yapılan testler sonucunda; öğretmenlerin medeni durumunun, mezuniyet durumunun ve branşlarının her bir maddeye verilen cevaplar açısından anlamlı fark oluşturmadığı gözlenmiştir. Cinsiyet değişkenine göre üç maddede görüş farklılığı tespit edilmişken; yaş değişkeninin 16, kıdem değişkeninin 19, okul türü değişkeninin ise 22 maddede görüş farklılığ oluşturduğu anlaşılmaktadır. Araştırmada ayrıca öğretmenlere, kendisinin veya bir yakınının öğrencisinin bu destekten yararlanıp yaralanmadığı da sorulmuştur. Bu soruya alınan cevaplarla oluşturulan kategorik değişkenle yapılan testler sonucunda da 5 maddeye ilişkin görüş farklılığ bulunmuştur.

\section{Cinsiyet Değişkenine Göre Öğretmenlerin Görüş Farklılıkları}

Çalışmamaya katılan 119 öğretmenin \%36,13'ü erkek \%63,87'si ise kadındır. Tablo 5'te öğretmenlerin cinsiyetlerinin görüşlerinin farklılığında anlamlı bir fark yaratmadığını test etmek için yapılan t-testi sonuçları görülmektedir. 
Tablo 5

Cinsiyet Değişkenine Göre Elde Edilen t-testi Sonuçları

\begin{tabular}{llccccc}
\hline & & $\mathbf{n}$ & $\overline{\mathbf{X}}$ & $\mathbf{S s}$ & $\mathbf{t}$ & $\mathbf{p}$ \\
\hline $\mathbf{M 6}$ & Kadin & 76 & 3,24 & 1,49 & $-1,056$ & 0,044 \\
& Erkek & 43 & 2,67 & 1,38 & & \\
$\mathbf{M 1 8}$ & Kadin & 76 & 3,09 & 1,28 & $-1,010$ & 0,026 \\
& Erkek & 43 & 2,56 & 1,18 & & \\
& Kadin & 76 & 3,26 & 1,40 & $-0,483$ & 0,019 \\
& Erkek & 43 & 2,65 & 1,27 & & \\
\hline
\end{tabular}

$\mathrm{p}<0,05$

Tabloya bakıldığında 26 sorudan 6,18 ve 21 'inci sorularda istatistiksel olarak anlamlı farklılık tespit edildiği görülmektedir. Diğer maddelere ilişkin yapılan t-testi sonuçları istatistiksel olarak anlamsız çıkmıştır. Bu sonuçlara göre kadın öğretmenler erkek öğretmenlere göre özel okullarda daha iyi ölçme değerlendirme yapıldığı, destek uygulamasının kapsamlı olduğu ve ihtiyacı olanların bu uygulamadan yararlanabildiği konusundaki görüşlere daha fazla katılmaktadır. İki grubun görüşleri de "kararsızım" kategorisinde yer almakla birlikte kadınların ortalama görüşü kategorinin üst sınırına, erkeklerin ortalama görüşü ise alt sınırına daha yakındır. Kadın öğretmenlerin, sınırlıda olsa, erkek öğretmenlere göre özel okullara destek verilmesi konusunda daha iyimser bir görüş sahibi olmalarının sebebinin ayrıca incelenmesi gerekebilir. Bu çalışmada elde edilen sonuç kadın öğretmenlerin özel öğretime destek konusunda çok istekli oldukları şeklinde yorumlanamaz. Öte yandan erkek öğretmenler kadın öğretmenlere göre biraz daha olumsuz görüşlere sahiptir. Bu durumun sebeplerinin anlaşılması için benzer çalışma gruplarındaki erkek öğretmenlerin mikro düzeyde, örneğin kendi aileleri ve yakınları ile ilgili olarak, eğitimin finansmanı yükünün ailelere daha fazla yüklenmesi yönündeki kamu politikalarıyla daha yakından ilgili olup olmadıkları incelenebilir.

\section{Farklı Yaş Gruplarındaki Öğretmenlerin Görüş Farklılıkları}

Çalışmaya katılan 119 öğretmen yaşlarına göre 4 kategoriye ayrılmıştır. Bu kategorilerden en yüksek pay1 \%46 ile 31-40 yaş grubu alırken $(\mathrm{n}=55), 51+$ yaş grubu $\% 4,2$ 'lik payla en düşük katılımı göstermiştir (n=5). Diğer kategoriler 20-30 (n=29) ve 40-50'dir (n=30). Tablo 6'da öğretmenlerin ankete maddelerine vermiş oldukları yanıtlardan elde edilen görüşlerinin yaş gruplarına göre farklılaşmasına ilişkin yapılan ANOVA sonuçları görülmektedir.

Tablo 6.

Yaș Değişkenine Göre Alınan Kruskal-Wallis ANOVA Sonuçları

\begin{tabular}{|c|c|c|c|c|c|}
\hline & $\mathrm{n}$ & $\chi^{2}$ & $\mathrm{df}$ & $\mathrm{p}$ & Fark \\
\hline$M 1$ & 119 & 10,381 & 3 & 0,016 & $1>3$ \\
\hline M6 & 119 & 8,050 & 3 & 0,045 & $1>3$ \\
\hline M7 & 119 & 13,757 & 3 & 0,003 & $1>2 ; 1>3$ \\
\hline M8 & 119 & 9,622 & 3 & 0,022 & $1>2$ \\
\hline M9 & 119 & 13,414 & 3 & 0,004 & $1>2 ; 1>3$ \\
\hline M10 & 119 & 8,701 & 3 & 0,034 & $1>2$ \\
\hline M11 & 119 & 10,548 & 3 & 0,014 & $1>3$ \\
\hline$M 12$ & 119 & 12,648 & 3 & 0,005 & $1>2 ; 1>3$ \\
\hline$M 13$ & 119 & 9,316 & 3 & 0,025 & $1>3$ \\
\hline$M 14$ & 119 & 15,386 & 3 & 0,002 & $1>2 ; 1>3$ \\
\hline M16 & 119 & 14,126 & 3 & 0,003 & $1>2$ \\
\hline$M 18$ & 119 & 20,310 & 3 & 0,000 & $1>2 ; 1>3$ \\
\hline M19 & 119 & 11,085 & 3 & 0,011 & $1>2 ; 1>3$ \\
\hline M20 & 119 & 15,708 & 3 & 0,001 & $1>2$ \\
\hline M21 & 119 & 16,411 & 3 & 0,001 & $1>2$ \\
\hline$M 22$ & 119 & 21,323 & 3 & 0,000 & $1>2 ; 1>3$ \\
\hline
\end{tabular}

Tablo 6 incelendiğinde farklı yaş gruplarındaki öğretmenlerin anket maddeleriyle ilgili çok fazla farklı düşünceye sahip oldukları ifade edilebilir. Ankette yer alan 26 sorudan 16'sında görüş ayrılığ1 yaşanmıştır. 20-30 yaş grubunda bulunan öğretmenler özel okullara destek verilmesini 
gerekçelendirirken; fiziksel şartlar, öğrenci sayısı, ders dışı etkinlikler ve yabancı dil eğitimi konularında özel okulların aha iyi durumda olduğu konusunda diğer yaş gruplarındaki öğretmenlerle hemfikirdir. Ancak ögretim kalitesi, ölçme değerlendirme ve rehberlik hizmetlerinde özel okulların daha iyi olduğu konusunda genç öğretmenler daha iyimserdir. Bu olanakların devlet okullarında daha kötü olduğu konusundaki maddelerin (8-14) tamamında görüş ayrılığı vardır. Genç öğretmenler daha kötümserdir. Özel öğretim desteğinin genel olarak değerlendirildiği diğer maddelere (15-26) bakıldığında, farklı yaş gruplarındaki öğretmenlerin süreçle ilgili yeterince bilgi sahibi olma konusunda kararsız olma görüşünü paylaştıkları anlaşılmaktadır. Yine de genç öğretmenler süreçle ilgili diğer maddelere verdikleri cevaplarda daha iyimserdirler: destek sağlanan öğrencilerin adil bir biçimde belirlendiği, uygulamanın kapsamlı olduğu, uygulamanın adaletli olduğu, isteyen herkesin başvurabildiği, ihtiyacı olanın yararlanabildiği ve uygulamanın gerekli olduğu konusundaki görüşlere üst yaş grubundakilere göre daha fazla katılmaktadırlar. Genç öğretmenlerin özel öğretime destek konusunda daha iyimser olmalarının sebebi, çalışma grubunda yer alan öğretmenlerin çoğunlukla özel okullarda çalışması olarak yorumlanabilir. $\mathrm{Bu}$ genç öğretmenlerin yaklaşık yarısının daha önce devlet okulunda çalışma yaşantılarının olduğu bilgi formunda yer alan bir sorudan elde edilmiş̧ir. Muhtemelen ücretli ögretmenlerin olumsuz çalışma koşullarının etkisiyle böyle bir görüşü ortaya çıkmış olduğu düşünülebilir. Devlet okullarında çalışan daha yaşlı öğretmenlerin de dörtte birinin daha önce özel okul deneyimi olduğu anlaşılmaktadır. Buna göre; iki grup da görüşlerini bildirirken daha önceki muhtemel olumsuz yaşantılarının etkisinde kalmış olabilir. Öğretmenler, verilen desteğin yeterli düzeyde olduğu, devlet okullarının kalitesini düşüreceği ve özel okulların kalitesini yükselteceği konularında kararsız kalmışlardır. Bu konularda yaş gruplarının görüşleri arasında anlamlı fark bulunmamıştır.

\section{Kıdemlerine Göre Öğretmenlerin Görüş Farklılıkları}

Kıdem ile yaş değişkenleriyle yapılan farklılık testlerinin birbirine benzer sonuçlar vermesi beklenir. Ancak son yıllarda öğretmenlerin göreve başlama yaşlarındaki düzensizliğin arttığından yola çıkarak bu iki değişkenle ilişkili test sonuçları ele alınmaktadır. Yaş değişkeni 4, kıdem değişkeni ise beş kategori olarak tasarlanmıştır. Kıdem değişkenine ilişkin kategorilere düşen öğretmen sayıları şöyledir: 1-5 yıl, 30; 6-10 y1l, 18; 11-15 yı1, 26; 16-20 y11, 22; ve 21+ yı1, 23. Öğretmenler kıdem değişkeninin kategorilerine daha iyi yayıldığından Tablo 7'de görülen ANOVA sonuçları Tablo 6 ile karşılaştırıldığında biraz farklılık göstermektedir.

Tablo 7.

Kıdem Değişkenine Göre Alınan Kruskal-Wallis ANOVA Sonuçları

\begin{tabular}{|c|c|c|c|c|c|}
\hline & $\mathrm{n}$ & $\chi^{2}$ & $\mathrm{df}$ & $\mathrm{p}$ & Fark \\
\hline M1 & 119 & 17,288 & 4 & 0,002 & $1>4 ; 1>5$ \\
\hline M3 & 119 & 10,040 & 4 & 0,040 & $1>5$ \\
\hline M6 & 119 & 16,934 & 4 & 0,002 & $1>3 ; 1>4 ; 1>5$ \\
\hline M7 & 119 & 19,916 & 4 & 0,001 & $1>3 ; 1>4 ; 1>5$ \\
\hline M8 & 119 & 21,760 & 4 & 0,000 & $1>2 ; 1>3 ; 1>4 ; 1>5$ \\
\hline M9 & 119 & 19,148 & 4 & 0,001 & $1>2 ; 1>3 ; 1>4 ; 1>5$ \\
\hline M10 & 119 & 15,975 & 4 & 0,003 & $1>3$ \\
\hline M11 & 119 & 12,777 & 4 & 0,012 & $1>3 ; 1>4 ; 1>5$ \\
\hline$M 12$ & 119 & 17,224 & 4 & 0,002 & $1>2 ; 1>3 ; 1>4 ; 1>5$ \\
\hline$M 13$ & 119 & 13,777 & 4 & 0,008 & $1>4$ \\
\hline M14 & 119 & 19,834 & 4 & 0,001 & $1>3 ; 1>4 ; 1>5$ \\
\hline M16 & 119 & 14,199 & 4 & 0,007 & $1>3$ \\
\hline$M 18$ & 119 & 23,714 & 4 & 0,000 & $1>3 ; 1>4 ; 1>5$ \\
\hline M19 & 119 & 12,338 & 4 & 0,015 & $1>4$ \\
\hline M20 & 119 & 14,673 & 4 & 0,005 & $1>3$ \\
\hline M21 & 119 & 18,086 & 4 & 0,001 & $1>3 ; 1>4$ \\
\hline M22 & 119 & 17,951 & 4 & 0,001 & $1>3 ; 1>5$ \\
\hline$M 25$ & 119 & 9,882 & 4 & 0,042 & $1>4$ \\
\hline
\end{tabular}

Tablo 7'de görüldüğü üzere, kıdem yıllarına göre öğretmenlerin anket maddelerine verdikleri cevaplarda görüş farkl1lığı mevcuttur. Anketteki 26 maddenin 19'una ilişkin olarak kıdemleri farklı 
öğretmenlerin görüşleri arasında anlamlı fark bulunmuştur. Kıdem değişkenine göre üst kategorilere daha fazla gözlem düştüğünden anlamlı fark bu sefer en az kıdemlilerle (1-5 yıl) en çok kıdemliler arasında daha fazla görülmektedir. Öte yandan görüş farlılıklarının kaynağı yine düşük kıdemlilerdir. Öğrenci başına desteği gerekçelendirirken özel okulları ve devlet okullarını karşılaştırmaları istendiğinde farklı kıdem gruplarındaki öğretmenler "özel okullarda fiziksel şartların daha iyi olduğu" ve "ders dışı etkinliklerin daha çok olduğu" görüşlerine topyekûn katılmaktadırlar. Özel okulların daha iyi olduğuna ilişkin diğer maddeler ile devlet okullarının daha kötü olduğuna ilişkin bütün maddelere (8-14) ilişkin verilen cevaplardan elde edilen puanlar arasında anlamlı fark vardır. Düşük kıdemli öğretmenler diğerlerine göre özel okulların daha iyi olduğu konusunda da iyimser, devlet okullarının daha kötü olduğu konusunda kötümserdir.

Kıdem değişkenine göre de, kıdemi düşük ve yüksek öğretmenler arasında öğrenci başına destek süreciyle ilgili detaylı bilgi sahibi olmama konusunda bir görüş ayrılığı bulunmamaktadır. Yine ortak bir nokta olarak; tüm kategorilerdeki öğretmenler öğrenci başına desteğin fazla olduğu görüşüne katılmamaktadır; bu konuda anlamlı bir görüş farkı yoktur. Öğrenci başına desteğin yeterli düzeyde olduğu, uygulamanın devlet okullarının kalitesini düşüreceği ve özel okullarının kalitesini yükselteceği konularında kararsız olma açısından da bir fark yoktur. Öğrenci başına destek süreciyle ilgili diğer maddelere verilen cevaplardan elde edilen puanlar ise; düşük kıdemli öğretmenlerin diğerlerine göre daha olumlu düşündüğünü ortaya koymaktadır. Düşük kıdemli öğretmenlerin özel öğretime destek konusunda daha iyimser olmalarının sebebinin, yaş değişkeninin etkisinde olduğu gibi düşük kıdemli öğretmenlerin devlet okullarında, kıdemli öğretmenlerin de özel okullardaki, daha önceki çalışma haytalarında karşılaşmış olabilecekleri olumsuzluklar olarak düşünülebilir Destek sağlanan öğrencilerin adil bir biçimde belirlendiği, uygulamanın kapsamlı olduğu, adaletli olduğu, isteyen herkesin başvurabileceği, ihtiyacı olanların bu destekten yararlanabileceği, uygulamanın gerekli olduğu ve özel sektörün çıkarına olduğu konularında düşük kıdemli öğretmenler ile diğerlerinin görüşleri arasında anlamlı fark vardir.

\section{Çalıştıkları Okul Türüne Göre Öğretmenlerin Görüş Farklılıkları}

Tablo 8'de öğretmenlerin çalıştıkları okulun finansman biçiminin görüşlerinde istatistiksel olarak anlamlı bir fark oluşturup oluşturmadığını anlamak için yapılan bağımsız t-testi sonuçları görülmektedir. Yaş değişkenine göre 16, kıdem değişkenine göre 19 maddede görüş ayrılığ tespit edilmişken okul türü değişkenine göre öğretmenlerin 26 sorudan 22 'sinde farklı düşündükleri ortaya çıkmaktadır. Görüş farklılığı olmayan üç madde, öğrencilere verilen desteğin yeterli düzeyde olduğu, uygulamanın devlet okullarının kalitesini düşüreceği ve özel okulların kalitesini yükselteceği ile ilgilidir. Bu konularda öğretmenler kararsız kalmıştır. Öğrenci başına destek uygulamasını gerekçelendirirken özel okul öğretmenleri tüm maddelerde özel okulların daha iyi devlet okullarının daha kötü olduğu konularında devlet okulu öğretmenlerine göre daha fazla katılmaktadırlar.

Özel okul öğretmenleri, kararsız alanda kalmakla birlikte, destek süreciyle ilgili detaylı bilgiye sahip oldukları ve destek sağlanan öğrencilerin adil biçimde belirlendiği ve uygulamanın adil olduğu konularında anlamlı bir biçimde daha olumlu düşünmektedirler. Uygulamanın kapsamlı olduğu, isteyen herkesin başvurabileceği, destekten ihtiyacı olanların yararlanabileceği, uygulamanın gerekli olduğu ve özel sektörün çıkarına olduğu görüşlerine özel okul öğretmenleri katılırken, devlet okulu öğretmenleri karasız kalmışlardır. 
Tablo 8

Çalışılan Okul Türü Değişkenine Göre Elde Edilen t-testi Sonuçları

\begin{tabular}{|c|c|c|c|c|c|c|}
\hline & & $\mathbf{n}$ & $\overline{\mathbf{x}}$ & SS & $t$ & p \\
\hline \multirow[t]{2}{*}{$M 1$} & Кати & 69 & 2,48 & 1,24 & $-6,828$ & 0,000 \\
\hline & Ozel & 50 & 4,06 & 1,25 & & \\
\hline \multirow[t]{2}{*}{$M 2$} & Кати & 69 & 3,41 & 1,35 & $-3,004$ & 0,003 \\
\hline & Ozel & 50 & 4,10 & 1,07 & & \\
\hline \multirow[t]{2}{*}{ M3 } & Кати & 69 & 3,54 & 1,24 & $-3,792$ & 0,000 \\
\hline & Ozel & 50 & 4,34 & 0,98 & & \\
\hline \multirow[t]{2}{*}{ M4 } & Кати & 69 & 3,45 & 1,30 & $-4,123$ & 0,000 \\
\hline & Ozel & 50 & 4,34 & 0,94 & & \\
\hline \multirow[t]{2}{*}{ M5 } & Кати & 69 & 3,41 & 1,31 & $-4,566$ & 0,000 \\
\hline & Ozel & 50 & 4,38 & 0,88 & & \\
\hline \multirow[t]{2}{*}{ M6 } & Кати & 69 & 2,39 & 1,26 & $-6,526$ & 0,000 \\
\hline & Ozel & 50 & 3,92 & 1,26 & & \\
\hline \multirow[t]{2}{*}{$M 7$} & Кати & 69 & 2,93 & 1,34 & $-7,076$ & 0,000 \\
\hline & Ozel & 50 & 4,44 & 0,81 & & \\
\hline \multirow[t]{2}{*}{ M8 } & Кати & 69 & 2,09 & 1,35 & $-4,514$ & 0,000 \\
\hline & Ozel & 50 & 3,26 & 1,47 & & \\
\hline \multirow[t]{2}{*}{ M9 } & Кати & 69 & 2,64 & 1,36 & $-3,275$ & 0,001 \\
\hline & Ozel & 50 & 3,48 & 1,42 & & \\
\hline \multirow{2}{*}{ M10 } & Кати & 69 & 2,97 & 1,36 & $-3,809$ & 0,000 \\
\hline & Ozel & 50 & 3,88 & 1,17 & & \\
\hline \multirow[t]{2}{*}{ M11 } & Кати & 69 & 2,70 & 1,30 & $-4,996$ & 0,000 \\
\hline & Ozel & 50 & 3,90 & 1,30 & & \\
\hline \multirow[t]{2}{*}{$M 12$} & Кати & 69 & 2,67 & 1,30 & $-4,738$ & 0,000 \\
\hline & Ozel & 50 & 3,84 & 1,38 & & \\
\hline \multirow[t]{2}{*}{ M13 } & Кати & 69 & 2,03 & 1,18 & $-5,920$ & 0,000 \\
\hline & Ozel & 50 & 3,40 & 1,34 & & \\
\hline \multirow[t]{2}{*}{$M 14$} & Кати & 69 & 2,06 & 1,07 & $-7,541$ & 0,000 \\
\hline & Ozel & 50 & 3,62 & 1,18 & & \\
\hline \multirow[t]{2}{*}{$M 15$} & Кати & 69 & 2,62 & 1,38 & $-2,070$ & 0,041 \\
\hline & Ozel & 50 & 3,12 & 1,15 & & \\
\hline \multirow[t]{2}{*}{ M16 } & Кати & 69 & 1,98 & 1,12 & $-3,431$ & 0,001 \\
\hline & Ozel & 50 & 2,68 & 1,10 & & \\
\hline \multirow[t]{2}{*}{$M 18$} & Кати & 69 & 2,43 & 1,17 & $-5,198$ & 0,000 \\
\hline & Ozel & 50 & 3,54 & 1,11 & & \\
\hline \multirow[t]{2}{*}{ M19 } & Кати & 69 & 2,29 & 1,20 & $-4,162$ & 0,000 \\
\hline & Ozel & 50 & 3,20 & 1,14 & & \\
\hline \multirow{2}{*}{$M 20$} & Кати & 69 & 2,75 & 1,37 & $-3,100$ & 0,002 \\
\hline & Ozel & 50 & 3,52 & 1,28 & & \\
\hline \multirow[t]{2}{*}{ M21 } & Кати & 69 & 2,57 & 1,31 & $-4,827$ & 0,000 \\
\hline & Ozel & 50 & 3,70 & 1,20 & & \\
\hline \multirow[t]{2}{*}{ M22 } & Кати & 69 & 2,81 & 1,35 & $-5,429$ & 0,000 \\
\hline & Ozel & 50 & 4,06 & 1,06 & & \\
\hline \multirow[t]{2}{*}{$M 25$} & Кати & 69 & 2,10 & 1,20 & $-6,798$ & 0,000 \\
\hline & Ozel & 50 & 3,58 & 1,13 & & \\
\hline
\end{tabular}

\section{Özel Öğretim Desteğinden Yararlanmasına Göre Görüş Farklııkları}

Çalışmada ankete katılan öğretmenlerin kendi çocuklarının ya da bir yakının daha önce özel öğretim desteği almış olup olmamasına göre bir kategorik değişken oluşturulmuştur. Ankete katılan öğretmenlerden \%75,63'ü kendilerinin veya bir yakınının daha önce özel öğretim desteği görmediğini belirtirken \%24,37'si böyle bir destek gördüğünü belirtmiştir. Tablo 9' da özel öğretim desteği gören ve görmeyen öğretmenlerin arasındaki görüş farklılıklarına ilişkin t-testi sonuçları yer almaktadır. 
Tablo 9

Özel Öğretim Desteğinden Yararlanmasına Göre Elde Edilen Mann Whitney U-testi Sonuçları

\begin{tabular}{llllllllc}
\hline & & $\mathbf{n}$ & $\overline{\mathbf{X}}$ & $\mathbf{S S}$ & $\mathbf{M W U}$ & $\mathbf{W W}$ & $\mathbf{z}$ & $\mathbf{p}$ \\
\hline $\boldsymbol{M 1}$ & Evet & 29 & 3,62 & 1,32 & 992,0 & $5.087,0$ & $-1,983$ & 0,047 \\
& Hayır & 90 & 2,99 & 1,49 & & & & \\
$\mathbf{M 2}$ & Evet & 29 & 4,28 & 0,88 & 888,5 & $4.983,5$ & $-2,676$ & 0,007 \\
& Hayır & 90 & 3,51 & 1,34 & & & & \\
$\mathbf{M 1 8}$ & Evet & 29 & 3,41 & 1,45 & 925,5 & $5.020,5$ & $-2,407$ & 0,016 \\
& Hayır & 90 & 2,73 & 1,16 & & & & \\
$\mathbf{M 2 1}$ & Evet & 29 & 3,55 & 1,53 & 937,5 & $5.032,5$ & $-2,323$ & 0,020 \\
& Hayır & 90 & 2,88 & 1,30 & & & & \\
$\mathbf{M 2 3}$ & Evet & 29 & 1,69 & 1,23 & $1.700,0$ & $5.795,0$ & $-2,588$ & 0,010 \\
& Hayır & 90 & 2,31 & 1,32 & & & & \\
\hline $\mathrm{p}<0,05$ & & & & & & & &
\end{tabular}

Tablo 9'a göre anketin 1, 2, 18. 21. ve 23. maddelerine ilişkin olarak daha önce özel öğretim desteğinden yararlanma durumuna göre görüş farklılığı oluştuğu anlaşılmaktadır. Bunlar özel okulların öğretim kalitesinin ve fiziksel şartlarının daha iyi olmasından dolayı öğrenci başına destek konusunda olumlu düşünülmesiyle ilgilidir. Destekten yararlananlar daha olumlu düşünmektedirler. Ayrıca uygulamanın kapsamlı olduğu ve ihtiyacı olanların uygulamadan yararlanabileceği konularında da daha önce destekten yararlanmış olanlar daha olumlu düşünmektedirler. Sağlanan destek düzeyinin fazla olduğu konusundaki görüşler karasız alanda yer almasına karşın, destekten yararlananların aldığı puan ortalamasının anlamlı bir biçimde düşük olduğu görülmektedir.

\section{Öğretmenlerin Önerileri}

Çalışmada uygulanan veri toplama aracıyla öğretmenlerden "başka bir görüş ve önerileri varsa bunu belirtmeleri”" istenmiştir. Elde edilen cevaplar üç kategori altında aşağı da görülmektedir:

Özel okullar yerine devlet okullarının desteklenmesine yönelik görüşler:

"Özel okullar yerine devlet okullarının desteklenmesi gerektiğini düşünüyorum."

"Özel okulların gereksiz olduğunu düşünüyorum. Devletin de özel okullara destek vermemesini istiyorum. Özel okulların şişirme not verdiği kanaatindeyim.”

"Devlet okullarına imkânlar sağlanmalı ve güçlendirilmeli. Eğitim parasız olmalı, herkese eşit hak tanınmalı."

Devlet okullarının iyileştirilmesine yönelik görüşler:

"Devlet okullarının da desteklenmesini istiyorum. Kalitenin eğitim anlamında değil de en azından temiz ortamda yapılmasını sağlar. Sağlıklı, temiz ortamda eğitim almak devlet okullarında yaşayan öğrencilerin de hakkıdır."

"Devlet okullarındaki öğrenci fazlalı̆̆ının eğitimin senkronize ilerlemesini boşvermişliğe geçirdiğini düşünüyorum."

"Çocuğunun geleceğinden umutlu olan anne ve babaların çocuklarını özel okula gönderebilmeleri için devlet desteği önemlidir. Ancak bu destek devlet okullarının fiziki ortamlarının iyileştirilmesi için de kullanılmalı, devlet okulları ötekileştirilmemeli. Eğitimde eşitlik olmalı!"

"Devlet okullarındaki imkânlar arttırılmalı. Özel kurumları desteklemenin yanında devlet okullarında etkinlik ve teknoloji konularına önem verilmeli."

Destek uygulamasının iyileştirilmesine ilişkin görüşler:

"Destek ihtiyaç sahibine ulaşmıyor."

"Dağıtımın adaletli olmadığı, yapılması gerektiğini düşünüyorum."

"İşyeri sahibi olup da gelirini zarar olarak gösterip destek alanların diğer öğrencilerin hakkını yediğini düşünüyorum. Destek verilen öğrencilerin iyi belirlenmesi ve desteğin ayrıca öğrenci başarısı gözönüne alınarak da verilmesini düşünüyorum."

Açık uçlu soruya verilen cevaplar arasında özel okullara verilen öğrenci başına desteğin uygun olmadığına ilişkin ifadeler vardır. Öte yandan, özel okullar desteklenirken devlet okullarının kalitesinin artırılması gereğine dikkat çekilmektedir. Ayrıca destekten yararlanan öğrencilerin belirlenmesinde kayıt dışı ekonomiden kaynaklanan adaletsizliklere vurgu yapılmaktadır. 


\section{Tartışma}

Araştırmadan elde edilen bulgular ortalama olarak öğretmenlerin öğrenci başına desteğe karş1 olmadıklarını, özel okulların daha iyi olmasından dolayı olumlu bulduklarını göstermektedir. Öğretmenler ortalama olarak destek sağlanan öğrencilerin adil bir biçimde belirlenmediğini ve sağlanan desteğin fazla olmadığını düşünmektedir. Ancak özel öğretime devlet desteği özelinde öğretmen görüşlerinin alındığı ilk çalışma bu olduğundan, görüşlerin genel olarak tartışılması zorunluluğu vardır. Genel olarak; bu bulgular liberal yaklaşımın iddialarını destekler niteliktedir. Çünkü ilgili bölümde ele alınan araştırma sonuçlarına göre; liberal yaklaşıma göre veliler ve öğretmenler gibi gruplar daha kaliteli olduğu gerekçesiyle eğitime özel sektörün katılımını desteklemektedir (Arslan, Satıcı ve Kuru, 2006; Özdemir ve Tüysüz, 2017; Uygun, 2003).

Cinsiyete göre elde edilen bulgular, kadın öğretmenlerin özel okullarda daha iyi ölçme değerlendirme yapıldığı, destek uygulamasını kapsamlı olduğu ve ihtiyacı olanların bu uygulamadan yararlanabildiği konusundaki görüşlere verdikleri cevaplardan aldıkları puan ortalamalarının erkek öğretmenlerin aldığı puanlara göre anlamlı bir şekilde yüksek olduğu ortaya çıkmaktadır. Diğer maddelere ilişkin görüşlerde cinsiyet açısından bir fark bulunmamıştır. Medeni durum, lisans eğitimi ve branş değişkenlerine göre yapılan testlerde de görüş farklılı̆̆ tespit edilmemiştir.

Yaş değişkenine göre 16, kıdem değişkenine göre 19, okul türü değişkenine göre de 22 maddede öğretmenler arasında anlamlı görüş farkı bulunmuştur. Yaşı küçük ve kıdemi düşük öğretmenler daha ziyade özel okullarda olduğundan bu üç değişkenle ilgili elde edilen sonuçlar birlikte ele alınabilir. Genç, kıdemsiz ve özel okulda çalışan öğretmenler, ileriki yaşlarda, kıdemli ve devlet okullarında çalışan öğretmenlere göre özel okullara destek uygulaması konusunda daha olumlu düşünmektedir; özel okulların şartlarının daha iyi, devlet okullarınınkini daha kötü olduğunu bu yüzden özel okullara destek verilmesinin olumlu olduğunu görüşündedir. Süreç hakkında daha fazla detaylı bilgi sahibi olduğunu ve sürecin uygulamasını olumlu bulduğunu ifade etmektedir.

Özel okullarda çalışan öğretmenlerin yarısı 20-30 yaş grubunda, yarısından fazlası ise 1-5 yıl arası kıdem grubunda yer almaktadır. Çalışmanın yürütüldüğ̈̈ ilçede özel okulda çalışan bu genç öğretmenler devlet okullarına atanmak için başvurmamış veya başvurmuş ama halihazırda atanamamış veya atanmayı bekleyen öğretmenlerdir. Bu öğretmenlerin devlet okulu tecrübesi büyük ölçüde kendi eğitimlerinden kaynaklanıyor olabileceği akla gelebilir. Öte yandan, devlet okullarında çalışan öğretmenlerden 15'i (/69) daha önce bir özel okulda çalıştığını belirtirken; özel okulda çalışmakta olup da daha önce bir devlet okulunda çalıştığını beyan edenlerin sayısı ise 34'tür. Ancak en küçük yaş grubu içinde bu durumda olanlar devlet okulu öğretmenleri arasında 2 kişi, özel okul öğretmenleri arasında ise 18'dir. En düşük kıdem (1-5 yıl) grubunda ise bu sayı devlet okulları için 1, özel okullar için 21'dir. Özel okullarda devlet okulu tecrübesi yaşadığını ifade eden genç ve kıdemsiz öğretmenlerinin bu tecrübeleri ücretli öğretmenlik şeklinde olabileceği gibi göreve başlayıp bırakma şeklinde de olabilir. Öyle anlaşılmaktadır ki, özel okullarda çalışan ve daha önce devlet okulunda çalışmış olan öğretmenlerin görüşleri öznel karşılaştırmalara dayanmaktadır. Bu öğretmenlerin devlet okullarıyla ilgili algılarının daha olumsuz, özel okullarla ilgili algılarının daha olumlu olduğu ifade edilebilir. Genç ve k1demsiz öğretmenlerin özel okullara öğrenci başına destek konusunda daha olumlu görüş bildirmelerinin sebebi, gençlerin beklentilerinin daha farklı olduğu şeklinde yorumlanabilir. Dolayısıyla görüş farklılıklarının ardında bir kuşak farkı olması kuvvetle muhtemeldir.

Daha önce kendisinin ya da bir yakınının çocuğunun özel öğretim desteğinden yararlanması durumuna göre öğretmen görüşlerine bakıldığında; destekten yararlananların özel okulların imkânlarının daha iyi olduğu ve uygulamanın olumlu olduğu yönündeki bazı görüşlere daha fazla katıldıkları anlaşılmaktadır. $\mathrm{Bu}$ bulgu da liberal yaklaşımı destekler niteliktedir.

Çalışmaya katılan öğretmenlerin açı uçlu soruya verdikleri cevaplardan, genel olarak özel okullara öğrenci başına destek uygulamasına karşı olmadıkları, devlet okullarının kalitesinin artırılması gerektiği konusunda hassasiyet belirttikleri ve destekten yararlanan öğrencilerin belirlenmesi ile ilgili prosedürün iyileştirilmesi gerektiği düşündükleri ortaya çıkmaktadır.

Araştırmanın sınırlılıkları içinde elde edilen bulgular, öğretmenlerin özel okullarda verilen eğitimin kalitesinin daha yüksek olduğu ve devlet okullarında verilen eğitimin kalitesinin artırılması gerektiği görüşündedir. Özel okullarda öğrenci başına devlet desteği verilmesine ilişkin genel olarak uygulamanın olumlu karşılandığını, destek sağlanan öğrencileri daha adil bir şekilde belirlenebileceği görüşünün paylaşıldığı ifade edilebilir. Bütün bu bulgular liberal yaklaşımı desteklemektedir. Anketin 26. sorusuna verilen yanıtta ise, öğretmenlerin bu desteğin özel sektörün çıkarına olduğu görüşüne katıldıkları 
görülmektedir. $\mathrm{Bu}$ bulgunun eleştirel yaklaşımı destekliyor olması mümkündür. Eleştirel açıdan yaklaş1lırsa, genel olarak, öğretmenlerin değişiklikleri zaman içinde özümseyebildikleri ifade edilebilir.

\section{Sonuçlar ve Öneriler}

Türkiye'de özel öğretim kurumlarının sayısı her geçen gün artmaktadır. Bu niceliksel artışın okulların kalitesi ile doğru orantılı olup olmadığ önemli bir tartışma konusudur. Özel okulların sayısındaki bu artış, özel okullardaki öğrencilere verilen devlet desteğinin uygulanması sürecinde gerekli olan kuralların ne kadar dikkate alındığını, ne kadar gerektiği gibi uygulandığını belirlemeyi zorlaştırmaktadır. Bu çalışmada elde edilen sonuçlardan biri, özel okul öğrencilerine verilen devlet desteğinin adil biçimde uygulanmadığ ve bu uygulamada eksikliklerin olduğu görüşüdür. Öğretmenlerin genel olarak özel öğretime olumlu yaklaşmaları, devlet okullarındaki öğretmenlerin özel sektöre daha az olumlu bakıyor olmaları liberal ve eleştirel yaklaşımların iddialarını destekler bulgular elde edilmesinin mümkün olduğunu göstermektedir. Ancak liberal-eleştirel tartışmasında gözden kaçmaması gereken bir husus, desteklenen veya eleştirilen devlet anlayışının ne liberal-bireyci ne de toplumcu olmayabileceğidir. Karma bir anlayış da var olabilir.

Öyle anlaşılıyor ki; Türkiye'de, öğrenci başına destek kaldırılsa bile, özel öğretime destek parasal ve prosedürel olarak devam edecektir. Dolayısıyla özel öğretimin genişlemesi öğrenci başına destek kaldırıldığında da devam edecek gibi görünmektedir. Çünkü bu konudaki esas faktörün veli tercihleri olduğu ortaya çıkmaktadır.

Araştırmada öğretmenlerin cinsiyet, yaş, kıdem, çalıştıkları okul türü, özel öğretim desteği durumu değişkenlerine göre özel okul öğrencilerine devlet desteği konusunda görüşlerinden elde edilen bulgular doğrultusunda araştırmacılara şu öneriler sunulmuştur:

1) Farklı bölgelerde (1. bölge, 2.bölge, 3.bölge vb.) öğretmenlik yapan öğretmen grupları ile çalışılarak bu konudaki görüşler tekrar incelenebilir. Ancak öğrenci başına destek uygulamasının kademeli olarak kaldırılacağı açıklandığından, özel sektöre desteğin diğer biçimleri sorulabilir.

2) Özel okula kayıtlı öğrencilerin velilerinin de araştırmaya dâhil edildiği çalışma grupları oluşturulabilir. Velilerin öğrencilerini neden özel okullara gönderdiğgi konusunda görüşleri de alınarak öğretmenler bilgilendirilebilir.

3) Eğitimde firsat eşitliğini sağlamak sosyal devletin gereğidir. Destekten gelir düzeyi düşük grupların yararlanması beklenirken kayıt dışı ekonomiden kaynaklanan problemlerin giderilmemesi mağdurların ikinci kez mağdur olmalarına neden olmaktadır: Önce vergi adaletsizliği sonra da destekten yararlanmada adaletsizlik. Dolayısıyla kayıt dışı ekonomi belirli bir düzeye indirilmeden ve vergi adaleti sağlanmadan kamu kaynaklarından yapılacak desteklerin üst gelir gruplarının yararına sonuç vereceği düşünülmelidir. Bu bağlamda, ilerde benzer araştırmaların metaanaliz çalışması ile raporlanması daha önemli bilgi birikimi sağlayabilir.

\section{Kaynakça}

Arslan, H., Satıcı, A. ve Kuru, M. (2006). Devlet ve özel ilköğretim okullarının etkililiğinin araştırılması. Eğitim ve Bilim, 31(142), 15-25.

Aydoğan, E. (2008). Eğitim sisteminde yeniden yapılanma ve özelleştirme adımları. Memleket Siyaset Yönetim, 3(6), 166-187.

Babanoğlu, M. P. ve Yardımcı, A. (2017). Turkish state and private school EFL teachers' perceptions on professional development. Çukurova Üniversitesi Ĕ̈itim Fakültesi Dergisi, 46(2), 789-803.

Belfield, C. R. (2000). Economic principles for education: theory and evidence. Cheltenham, UK: Edward Elgar.

Belfield, C. R. (Ed.). (2006). Modern classics in the economics of education: volume I-II. Cheltentham, UK: Edward Elgar Publishing Ltd.

Bellibaş, M. Ş. v e Gedik, Ş. (2014). Özel ve devlet okullarında çalışan müdürlerin öğretim liderliği becerileri açısından karşılaştırılması: karma yöntem. Kuram ve Uygulamada Eğitim Yönetimi, 20(4), 453-482.

Benson, C. S. (1995). Educational financing. In Carnoy, M. International encyclopedia of economics of education. (2nd edition). (pp. 408-411).

Bifulco, R. \& Reback, R. (2014). Fiscal impacts of charter schools: lessons from New York. Education Finance and Policy, 9(1), 86-107. 
Boz, T. ve Yıldırım, A. (2014). 4+4+4 Eğitim sisteminde birinci sınıf öğretmenlerinin karşılaştığı zorluklar. Başkent University Journal of Education, 1(2), 54-65.

Bray, M. (1996). Counting the full cost: parental and community financing of education in East Asia. Washington D.C.: The World Bank.

Coombs, P. H. \& Hallak, J. (1987). Cost analysis in education: a tool for policy and planning. The World Bank, Baltimore: Johns Hopkins University Press.

Çam, T. (2006). Küreselleşme ve eğitim, 1980 sonrası neoliberal eğitim politikalarının Türk ĕgitim sistemine etkisi. Yayınlanmamış yüksek lisans tezi, Ege Üniversitesi, İzmir.

Çokgezen, M. ve Terzi, N. (2008). Türkiye'de devletin eğitime müdahalesinin yeterli gerekçesi var mı? Liberal Düşünce, 13(49), 5-23.

Eğitim-Sen (2015). Eğitimde özelleştirmenin yeni adresi: temel liseler. Ankara: Eğitim Sen Yayınları.

Eurydice. (2014). Financing schools in Europe: mechanisms, methods and criteria in public funding. Eurydice Report. Luxembourg: Publications Office of the European Union.

Friedman, M. (2002). The role of government in education. In R. Friedman (Ed.), Capitalism and freedom, 3E (pp. 85-107). Chicago, IL: University of Chicago Press.

Kalkan, B. (2014). Eğitim kuponu: eğitimde fırsat eşitliği için bir öneri. Liberal Düşünce, 19(76), 63 99.

Keskin Demirer, D. (2012). Eğitimde piyasalaşma ve öğretmen emeğinde dönüşüm. Çalışma ve Toplum, $1,161-186$.

Kulaksızoğlu, A., Çakar, M. ve Dilmaç, B. (1999a). Türkiye'de ve dünyada özel okulların yapısı ve işleyişi. Marmara Üniversitesi Atatürk Eğitim Fakültesi Eğitim Bilimleri Dergisi, 11, 219-232.

Kulaksızoğlu, A., Çakar, M. ve Dilmaç, B. (1999b). Türkiye'de özel okullar hakkındaki tutumla ilgili bir araştırma. Marmara Üniversitesi Atatürk Eğitim Fakültesi Ĕ̈itim Bilimleri Dergisi, 11, 233 246.

Kurul, N. (2012). Eğitim finansmant. 2. bask1. Ankara: Siyasal Kitabevi.

MEB. (2012). Milli Ĕ̆itim Bakanlı̆̆ı Özel Öğretim Kurumları Yönetmeliği. Resmi Gazete Tarihi: 20.03.2012, Resmi Gazete Sayıs1: 28239. www.mevzuat gov.tr adresinden 17.10.2018 tarihinde erişilmiştir.

MEB. (2014-2017). 2015, 2016, 2017 ve 2018 bütçe sunuş konuşmaları. http://sgb.meb.gov.tr/www/dokumanlar/icerik/30 adresinden 24.10 .2018 tarihinde erişilmiştir.

MEB. (2013-2018). Milli eğitim istatistikleri, 2012-13, 2013-14, 2014-15, 2015-16, 2016-17 ve 201718. http://sgb.meb.gov.tr/www/resmi-istatistikler/icerik/64 tarihinde erişilmiştir.

MEB. (2018). 5580 sayılı kanun kapsamındaki özel okullarda öğrenim gören/görecek öğrenciler için verilecek eğitim ve öğretim desteği uygulama e-kılavuzu. https://ookgm.meb.gov.tr/meb_iys_dosyalar/2018_08/16180149_2018-

2019 egitim_ogretim_destegi_kilavuzu.pdf adresinden 24.10.2018 tarihinde erişilmiştir.

Mezitli MĒM. (2018). Mezitli İlçe Milli Eğitim Müdürlüğü resmi web sitesi istatistikleri, http://mezitli.meb.gov.tr/ adresinden 16.10.2018 tarihinde erişilmiştir.

Özan, M. B., Polat, H., Gündüzalp, S. ve Yaraş, Z. (2015). Okul yöneticilerinin dershane dönüşümüne ilişkin görüşleri. Abant İzzet Baysal Üniversitesi Eğitim Fakültesi Dergisi, 15(2), 259-279.

Özdemir, A. ve Tüysüz, F. (2017). Özel okul yatırımları için Türkiye'deki 81 ilin çok kriterli karar verme yöntemleri ile stratejik analizi. Marmara Üniversitesi Atatürk Eğitim Fakültesi Eğitim Bilimleri Dergisi, 45, 93-114.

Sutton, L. C. \& King. R. A. (2013). Financial crisis not wasted: shift in state power and voucher expansion. Journal of Education Finance, 38(4), 283-303.

Şentürk, İ. (2008). Pierre Bourdieu'nun neoliberalizm eleştirisi bağlamında eğitim yönetimini yeniden düşünmek. Eskişehir Osmangazi Üniversitesi Sosyal Bilimler Dergisi, 11(2), 73-98.

Şimşek, H. (2018). Türkiye'de devlet okulu neden hedefte? Yeni liberal ve yeni muhafazakar taktikler. İstanbul: Gamze Yayınc1lık.

TBMM. (2018). Millî Eğitim Bakanı Ziya Selçuk’un, 2019 y1lı merkezi yönetim bütçe kanun teklifi (1/276) ile 2017 yılı merkezi yönetim kesin hesap kanunu tasarısı (1/275) ve Sayıştay tez-kereleri hakkında sunumu. TBMM Plan ve Bütçe Komisyonu Tutanak Dergisi, 27/2(11), 7-19.

TEDMEM (2015). Eğitim değerlendirme raporu, 2015. Ankara: Türk Eğitim Derneği.

TEDMEM (2016). Eğitim değerlendirme raporu, 2016. Ankara: Türk Eğitim Deneği. 
TÜİK (2018). Eğitim harcamaları istatistikleri, 2017. http://www.tuik.gov.tr adresinden 23.01.2018 tarihinde erişilmiştir.

Türkoğlu, M. E. ve Aypay, A. (2015). Özel okul öğretmenlerinin öğretmen hesap verebilirliğine dair düşünceleri. Eğitimde Politika Analizi Dergisi, 4(1), 7-32.

Uygun, S. (2003). Türkiye'de dünden bugüne özel okullara bir bakış: gelişim ve etkileri. Ankara Üniversitesi Ĕgitim Bilimleri Fakültesi Dergisi, 36(1-2), 107-120.

Ünal, L. I. (1996). Eğitim ve yetiştirme ekonomisi. Ankara: Epar Yayınları.

Ünal, L. I. (2005). Öğretmen imgesinde neoliberal dönüşüm. Ĕ̆itim, Bilim, Toplum, 3(11), 5-15.

Woodhall, M. (2004). Cost-benefit analysis in educational planning. 4th ed. Paris: UNESCO. 